\title{
Bermanella marisrubri gen. nov., sp. nov., a genome-sequenced gammaproteobacterium from the Red Sea
}

Correspondence

David R. Arahal

arahal@uv.es

\author{
Jarone Pinhassi, ${ }^{1}$ María J. Pujalte, ${ }^{2,3}$ Javier Pascual,, ${ }^{3,4}$ José M. González, ${ }^{5}$ \\ Itziar Lekunberri, ${ }^{6}$ Carlos Pedrós-Alió ${ }^{6}$ and David R. Arahal ${ }^{2,3}$ \\ ${ }^{1}$ Marine Microbiology, Department of Biology and Environmental Sciences, University of Kalmar, \\ SE-39182 Kalmar, Sweden \\ ${ }^{2}$ Colección Española de Cultivos Tipo (CECT), Universitat de València, Campus de Burjassot, \\ E-46100 València, Spain \\ ${ }^{3}$ Departamento de Microbiología y Ecología, Universitat de València, Campus de Burjassot, \\ E-46100 València, Spain \\ ${ }^{4}$ Instituto Cavanilles de Biodiversidad y Biología Evolutiva, Universitat de València, Campus de \\ Burjassot, E-46100 València, Spain \\ ${ }^{5}$ Departamento de Microbiología y Biología Celular, Facultad de Farmacia, Universidad de La \\ Laguna, La Laguna, Tenerife, Spain \\ ${ }^{6}$ Institut de Ciències del Mar-CMIMA (CSIC), Passeig Marítim de la Barceloneta 37-49, E-08003 \\ Barcelona, Catalunya, Spain
}

\begin{abstract}
A novel heterotrophic, marine, strictly aerobic, motile bacterium was isolated from the Red Sea at a depth of $1 \mathrm{~m}$. Analysis of its 16S rRNA gene sequence, retrieved from the whole-genome sequence, showed that this bacterium was most closely related to the genera Oleispira, Oceanobacter and Thalassolituus, each of which contains a single species, within the class Gammaproteobacteria. Phenotypic, genotypic and phylogenetic analyses supported the creation of a novel genus and species to accommodate this bacterium, for which the name Bermanella marisrubri gen. nov., sp. nov. is proposed. The type strain of Bermanella marisrubri is RED65 ${ }^{\top}$ $\left(=\right.$ CECT $7074^{\top}=$ CCUG $\left.52064^{\top}\right)$.
\end{abstract}

Molecular biological techniques have demonstrated that members of the class Gammaproteobacteria are predominant among the marine bacterioplankton, together with members of the Alphaproteobacteria and the Bacteroidetes (Giovannoni \& Rappé, 2000). Furthermore, the phylogenetic diversity of cultured and uncultured gammaproteobacteria accounts for $25-44 \%$ of the global marine bacterioplankton diversity, as revealed by analysis of $16 \mathrm{~S}$ rRNA gene sequences reported in public databases (Hagström et al., 2002). In previous studies, we have described several novel marine bacteria isolated from seawater collected in the Mediterranean Sea at the Blanes Bay Microbial Observatory (Pinhassi et al., 2006, 2007;

The GenBank/EMBL/DDBJ accession numbers for the 16S rRNA gene sequence and the genome sequence of strain RED65 ${ }^{\top}$ are $A Y 136131$ and $\mathrm{AAOH} 0000000$, respectively.

A scanning electron micrograph of cells of strain RED65 ${ }^{\top}$ and maximum-parsimony and maximum-likelihood phylogenetic trees based on almost-complete $16 \mathrm{~S}$ rRNA gene sequences of strain RED $65^{\top}$ and closely related species are available as supplementary figures with the online version of this paper.
Arahal et al., 2007). In the present study, we describe a novel bacterium, designated strain $\operatorname{RED} 65^{\mathrm{T}}$, isolated from a surface-seawater sample collected from the Gulf of Eilat in the northern Red Sea $\left(29^{\circ} 51^{\prime} \mathrm{N} 34^{\circ} 94^{\prime}\right.$ E) on 24 September 2000 .

The sample was inoculated in $0.2-\mu \mathrm{m}$-pore-size sterilefiltered seawater (inoculum/filtered seawater, 1:9) and then incubated in the dark for $48 \mathrm{~h}$ at $28{ }^{\circ} \mathrm{C}$. For details on the experimental set-up, see Pinhassi \& Berman (2003). For strain isolation, $0.1 \mathrm{ml}$ of a $100 \times$ dilution of sample water was spread onto agar plates prepared with seawater samples taken at the Gulf of Eilat. The formulation of the isolation medium was a modification of medium 2216 (ZoBell, 1946) and consisted of $750 \mathrm{ml}$ seawater, $250 \mathrm{ml}$ MilliQ water, $5 \mathrm{~g}$ peptone and $1 \mathrm{~g}$ yeast extract; for solid medium, $15 \mathrm{~g}$ agar was added. Sterilization was performed at $120{ }^{\circ} \mathrm{C}$ for $20 \mathrm{~min}$. After primary isolation and purification, strain RED65 ${ }^{\mathrm{T}}$ was cultivated at room temperature on the same medium and stored at $-80{ }^{\circ} \mathrm{C}$ in isolation medium with $25 \%(\mathrm{v} / \mathrm{v})$ glycerol. 
The complete 16S rRNA gene sequence of strain RED65 ${ }^{\mathrm{T}}$ was $1533 \mathrm{nt}$ in length. This sequence was compared with public sequences in the EMBL gene databases by using the BLAST program (National Center for Biotechnology Information; http://ncbi.nlm.nih.gov/). Related sequences were further analysed using the ARB package (Ludwig et al., 2004; http://www.arb-home.de). Sequence alignments were corrected manually using the sequence editor ARB_EDIT. Phylogenetic analysis using various treeing methods (neighbour joining, maximum parsimony and maximum likelihood) and data subsets were performed using the appropriate ARB tools (Ludwig et al., 1998). Fig. 1 shows the tree derived from the neighbour-joining method using Jukes-Cantor evolutionary corrections. Phylogenetic analysis revealed that strain RED $65^{\mathrm{T}}$ was only distantly related to the species shown in Fig. 1: the highest sequence similarity obtained was with Oceanobacter kriegii IFO $15467^{\mathrm{T}}$ (92.1\%); the remaining strains showed less than $91.9 \%$ similarity. Both the high bootstrap values (Fig. 1) and the data from comparisons of the local topologies obtained using several treeing methods (see Supplementary Figs S1 and S2, available in IJSEM Online) serve to confirm that strain $\mathrm{RED}^{\mathrm{T}}{ }^{\mathrm{T}}$ clusters consistently with Oleispira antarctica $\mathrm{RB}-\mathrm{8}^{\mathrm{T}}$ in the first instance and thereafter with a node formed by Oceanobacter kriegii IFO $15467^{\mathrm{T}}$ and Thalassolituus oleivorans MIL- $1^{\mathrm{T}}$.

Whole-genome sequencing was carried out by the J. Craig Venter Institute through the Gordon and Betty Moore Foundation Initiative in Marine Microbiology (https:// research.venterinstitute.org/moore/). Genome sequencing revealed a DNA G $+\mathrm{C}$ content of $44.0 \mathrm{~mol} \%$. The genome size of strain $\mathrm{RED}^{\mathrm{T}} \mathrm{T}^{\mathrm{T}}$ is approximately $3.53 \mathrm{Mbp}$ (3314 putative open reading frames). Pulsed-field gel electrophoresis analysis of endonuclease digests of genomic DNA from Oleispira antarctica $\mathrm{RB}-8^{\mathrm{T}}$ and T. oleivorans MIL-1 ${ }^{\mathrm{T}}$ gave estimated genome sizes of 2.0 and $2.2 \mathrm{Mbp}$, respectively (Yakimov et al., 2003, 2004). The DNA $\mathrm{G}+\mathrm{C}$ content of Oleispira antarctica RB-8 ${ }^{\mathrm{T}}$ (41.6 $\left.\mathrm{mol} \%\right)$ is relatively close to that of strain RED65 ${ }^{\mathrm{T}}$, but that of $T$. oleivorans MIL- ${ }^{\mathrm{T}}$ (53.6 mol\%) differs by almost 10 units; that of Oceanobacter kriegii $197^{\mathrm{T}}$ (56.1 mol\%) exceeds the $\mathrm{G}+\mathrm{C}$ content of RED $65^{\mathrm{T}}$ by an even greater margin, being at a level that is usually regarded as a threshold for genus separation (Trüper \& Schleifer, 2006).

Strain RED65 ${ }^{\mathrm{T}}$ was subsequently investigated using previously described methods for phenotypic characterization (Macián et al., 2001, 2005). Optical microscopy of bacterial cultures on wet mounts showed that cells were motile, thin, flexuous spirilla. To elaborate the cell morphology, cells were grown at $21{ }^{\circ} \mathrm{C}$ in marine broth 2216 (Difco) until early exponential phase (24-48 h incubation), fixed with glutaraldehyde and filtered onto $0.2-\mu \mathrm{m}$-pore-size polycarbonate filters (Nuclepore). Samples were subjected to sequential ethanol dehydration, critical-point drying with $\mathrm{CO}_{2}$ and coating with silver before being viewed in a Hitachi S-3500N scanning electron microscope. Cells of strain $\mathrm{RED}^{\mathrm{T}} 5^{\mathrm{T}}$ appear as thin spirilla, $0.3-0.6 \mu \mathrm{m}$ in diameter and 1.8-4.5 $\mu \mathrm{m}$ in length (Fig. 2). In some cells, the curvature was less well defined. Budding could be seen at the tips of some cells, and coccoid bodies could be observed in older cultures (Supplementary Fig. S3).

On marine agar 2216 (MA; Difco), strain RED65 ${ }^{\mathrm{T}}$ produced regular, translucent, non-pigmented, tiny colonies that did not swarm or luminesce. Notably, colonies appeared to grow immediately below, rather than on top of, the agar surface. Strain RED65 ${ }^{\mathrm{T}}$ was able to grow on salt tolerance agar (tryptone, $1 \%$, w/v; yeast extract, $0.3 \%$, w/v; agar, $1.5 \%$, w/v) with the addition of $\mathrm{Na}^{+}$(as $2 \% \mathrm{NaCl}$,

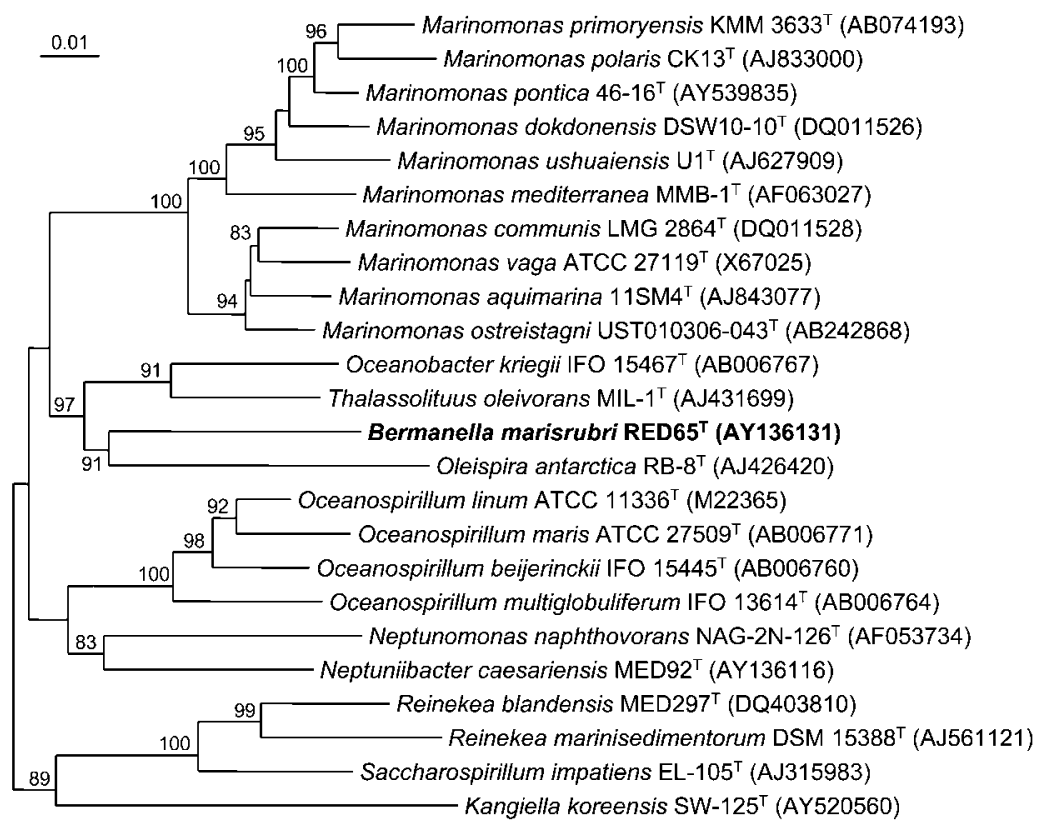

Fig. 1. Neighbour-joining phylogenetic tree, based on almost-complete 16S rRNA gene sequences of strain RED $65^{\top}$ and closely related species. Bootstrap percentages (based on 1000 resamplings) $>60 \%$ are shown at branching points. Sequence accession numbers are given in parentheses. Bar, 1 estimated substitution per 100 bases. 


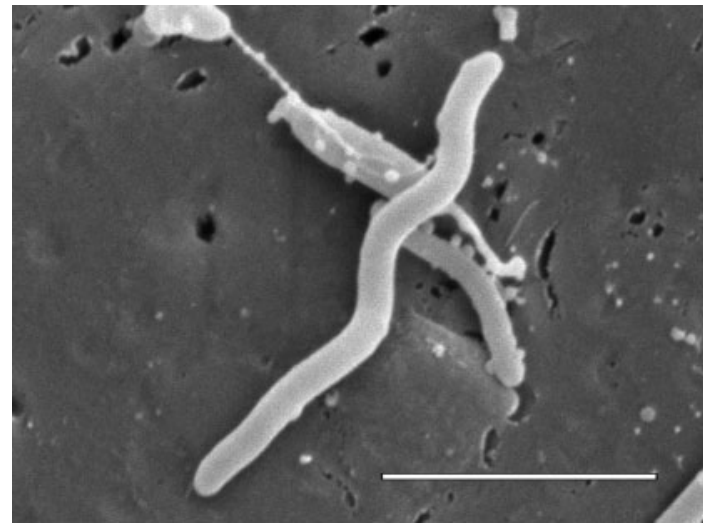

Fig. 2. Scanning electron micrograph of cells (in the exponential growth phase) of strain RED65 $5^{\mathrm{T}}$ immobilized on a $0.2-\mu \mathrm{m}$-poresize polycarbonate filter. Bar, $2 \mu \mathrm{m}$.

$\mathrm{w} / \mathrm{v})$. However, strain $\mathrm{RED}^{\mathrm{T}} \mathrm{T}^{\mathrm{T}}$ has a specific requirement for $\mathrm{Na}^{+}$, as no growth was obtained when $\mathrm{Na}^{+}$was replaced with $\mathrm{K}^{+}$. The salinity range that supported growth on diluted MA or in MA supplemented with $\mathrm{NaCl}$, as reported by Macián et al. (2005), was $0.9-12 \%$ (w/v) total salts, and thus RED65 ${ }^{\mathrm{T}}$ is a slight halophile. Oleispira antarctica, Oceanobacter kriegii and T. oleivorans also have a requirement for $\mathrm{Na}^{+}$, but they exhibit lower ranges of salinity for growth (Table 1).
Strain RED65 ${ }^{\mathrm{T}}$ is mesophilic, growing on MA from 15 to $42{ }^{\circ} \mathrm{C}$, but not at 4 or $45^{\circ} \mathrm{C}$. In contrast, Oleispira antarctica is markedly psychrophilic. Oceanobacter kriegii and $T$. oleivorans are also mesophilic but have lower optimal temperatures than does strain RED65 ${ }^{\mathrm{T}}$.

Strain RED65 ${ }^{\mathrm{T}}$ was oxidase- and catalase-positive and was unable to grow under anaerobic conditions, either through glucose fermentation or by nitrate respiration. The same results were reported for Oleispira antarctica, Oceanobacter kriegii and T. oleivorans except that, in the case of Oleispira antarctica, nitrate was used for anaerobic respiration (Baumann et al., 1972; Bowditch et al., 1984; Yakimov et al., 2003, 2004). Strain RED65 ${ }^{\mathrm{T}}$ was negative for arginine dihydrolase, ornithine decarboxylase and indole production from tryptophan. It hydrolysed Tween 80 and lecithin but not alginate, agar, casein, DNA or starch. The strain was unable to grow in marine broth 2216 (Difco) with $12 \%(\mathrm{w} / \mathrm{v})$ gelatin. Other enzyme activities of the strain were tested using the API ZYM (bioMérieux) gallery: the tests were performed according to the manufacturer's instructions, except that the cells were suspended in a $3.5 \%$ sea salts solution before they were added to the API ZYM strips, and the strips were incubated for $20 \mathrm{~h}$ at $26{ }^{\circ} \mathrm{C}$. The results are shown in the species description.

Utilization of sugars, alcohols and organic acids as sole carbon and energy sources was analysed on basal medium agar [50 mM Tris/HCl, pH 7.5, $19 \mathrm{mM} \mathrm{NH}_{4} \mathrm{Cl}, 0.33 \mathrm{mM}$ $\mathrm{K}_{2} \mathrm{HPO}_{4} \cdot 3 \mathrm{H}_{2} \mathrm{O}$ and $0.1 \mathrm{mM} \mathrm{FeSO}{ }_{4} \cdot 7 \mathrm{H}_{2} \mathrm{O}$ in half-strength

Table 1. Phenotypic characteristics that serve to differentiate strain RED $65^{\top}$ from the type strains of closely related species

Strains: 1, RED65 $^{\mathrm{T}}$ (data from this study); 2, Oleispira antarctica RB- $8^{\mathrm{T}}$ (data from Yakimov et al., 2003); 3, Oceanobacter kriegii $197^{\mathrm{T}}$ (Baumann et al., 1972; Bowditch et al., 1984; Sakane \& Yokota, 1994); 4, T. oleivorans MIL-1 ${ }^{\mathrm{T}}$ (Yakimov et al., 2004). +, Positive; -, negative; w, weakly positive.

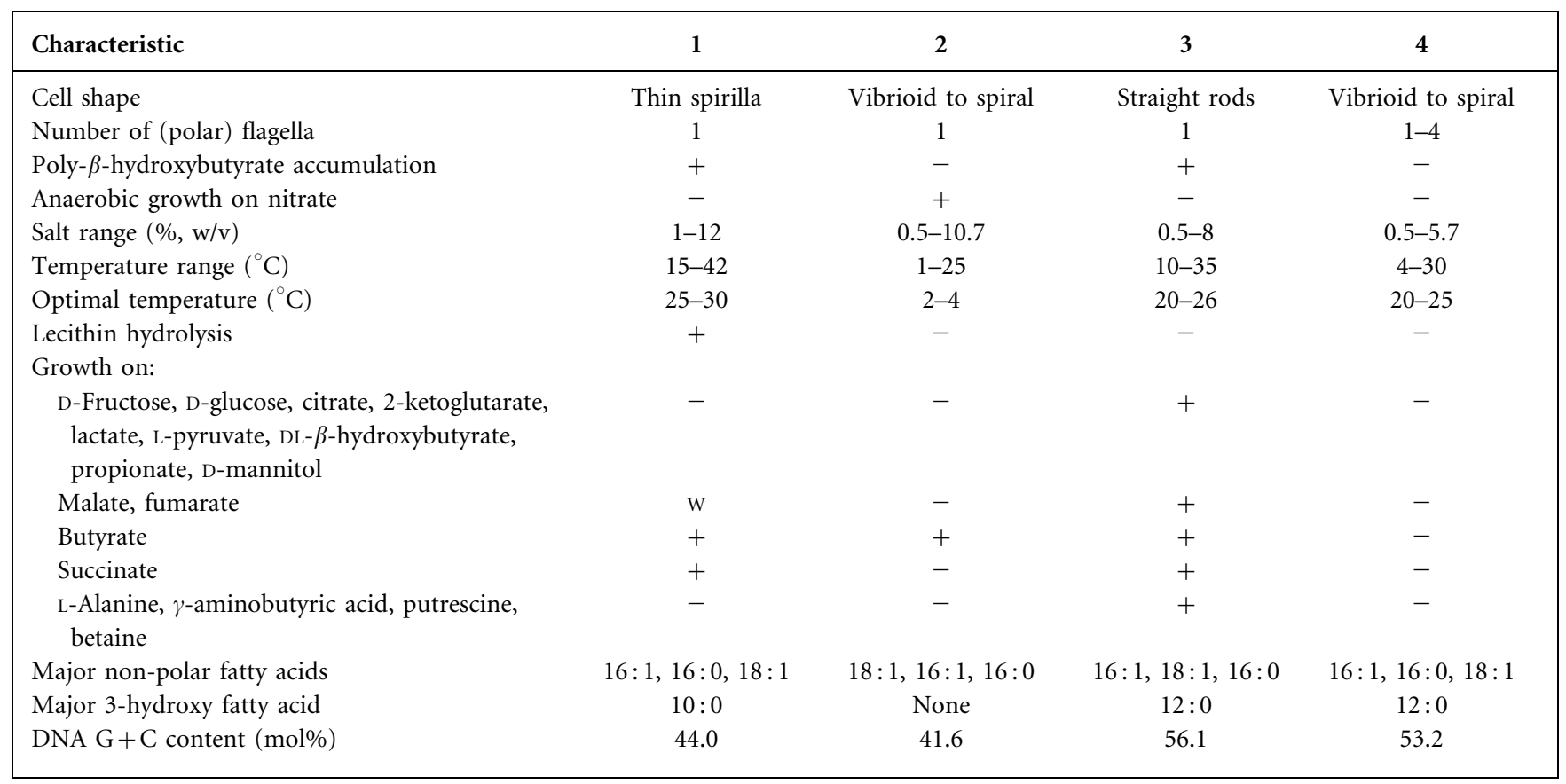


artificial seawater solidified with $1.3 \%(\mathrm{w} / \mathrm{v})$ purified agar (Oxoid) (Baumann \& Baumann, 1981)]. Amino acids and amines were tested as sole carbon, nitrogen and energy sources on basal medium agar without $\mathrm{NH}_{4} \mathrm{Cl}$. Compounds were added at $2 \mathrm{~g} \mathrm{l}^{-1}$. Positive control plates were prepared with yeast extract $\left(5 \mathrm{~g} \mathrm{l}^{-1}\right)$, while negative control media consisted of basal medium agar. Growth was monitored for 12 days. Of the 55 compounds tested, only a few organic acids enabled growth of strain RED65 $5^{\mathrm{T}}$ : acetate, butyrate, fumarate (weak), malate (weak) and succinate. Compared with strain RED65 ${ }^{\mathrm{T}}$, Oleispira antarctica and $T$. oleivorans had narrower ranges of utilizable resources whereas Oceanobacter kriegii had the greatest nutritional versatility (Table 1). Biolog GN2 MicroPlates were also employed according to the manufacturer's instructions except that the suspension medium was supplemented with $1.5 \%(\mathrm{w} / \mathrm{v}) \mathrm{NaCl}$. Again, few positive results were obtained. Strain RED65 ${ }^{\mathrm{T}}$ gave strong responses to Tweens 40 and 80 and weak responses to pyruvic acid methyl ester and succinic acid.

The cellular fatty acid composition of strain RED $65^{\mathrm{T}}$ (grown on marine agar at $30{ }^{\circ} \mathrm{C}$ ) was determined by GLC at the Deutsche Sammlung von Mikroorganismen und Zellkulturen (DSMZ; Braunschweig, Germany), using a method described previously (Kämpfer \& Kroppenstedt, 1996). Polar lipid and analysis of strain RED65 ${ }^{\mathrm{T}}$ was carried out by the Identification Service of the DSMZ and Dr B. J. Tindall (DSMZ). The cellular fatty acid pattern, in decreasing order of abundance, was $16: 1 \omega 7 c / 15: 0$ iso 2$\mathrm{OH}(38.03 \%), 16: 0(20.26 \%), 18: 1 \omega 9 c(12.06 \%), 10: 0$ $3-\mathrm{OH}(6.54 \%), 14: 0(5.42 \%), 18: 1 \omega 7 c(4.97 \%), 10: 0$ $(4.58 \%)$, unknown fatty acid with an equivalent chainlength of $11.799(3.72 \%), 18: 0(2.73 \%), 12: 0(1.12 \%)$, $16: 12-\mathrm{OH}(0.30 \%)$ and $16: 0$ iso $(0.28 \%)$. Important chemotaxonomic differences were identified between strain $\mathrm{RED}^{\mathrm{T}}{ }^{\mathrm{T}}$ and its closest neighbours (Table 1).

The low levels of 16S rRNA gene sequence similarity between $\operatorname{RED} 65^{\mathrm{T}}$ and all other established species lend strong support to the consideration of this strain as a member of a separate genus and species. Furthermore, this strain can be readily distinguished from its closest relatives on the basis of a significant number of phenotypic and genotypic traits, as identified in this work. Thus, strain RED $65^{\mathrm{T}}$ represents a novel genus and species, for which the name Bermanella marisrubri gen. nov., sp. nov. is proposed.

\section{Description of Bermanella gen. nov.}

Bermanella (Ber.ma.nel'la. N.L. fem. dim. n. Bermanella named after the aquatic microbial ecologist $\mathrm{Dr}$ Tom Berman).

Gram-negative, strictly aerobic, chemo-organotrophic bacteria. Oxidase- and catalase-positive. Cells are motile, thin spirilla. Gas vesicles are not observed. Poly- $\beta$-hydroxybutyrate granules are produced. Slightly halophilic; no growth without seawater or the addition of combined marine salts to the medium. Mesophilic. Do not ferment carbohydrates, as determined on anaerobic Hugh \& Leifson O/F medium (Difco) with half-strength artificial seawater (Baumann \& Baumann, 1981). Stenotrophic; the only carbon sources that serve as single carbon sources are organic acids. The genus is affiliated to the class Gammaproteobacteria. The type species is Bermanella marisrubri.

\section{Description of Bermanella marisrubri sp. nov.}

Bermanella marisrubri (ma.ris.ru'bri. L. n. mare sea; L. adj. ruber-bra-brum red; N.L. gen. n. marisrubri of the Red Sea).

Has the characteristics described below in addition to those given in the genus description. Cells are $0.3-0.6 \mu \mathrm{m}$ in diameter and $1.8-4.5 \mu \mathrm{m}$ in length. Does not reduce nitrate to nitrite or gas. Requires at least $1 \%(\mathrm{w} / \mathrm{v}) \mathrm{NaCl}$ or marine salts and tolerates up to $12 \%(\mathrm{w} / \mathrm{v})$ salts. Growth occurs at $15-42{ }^{\circ} \mathrm{C}$; no growth at 4 or $45{ }^{\circ} \mathrm{C}$. Hydrolyses Tween 80 and lecithin. Does not hydrolyse gelatin (no growth in medium), alginate, agar, casein, DNA or starch. Negative for arginine dihydrolase, ornithine decarboxylase and indole production from tryptophan. Utilizes acetate, butyrate and succinate as sole carbon and energy sources. Weak growth is obtained on fumarate, malate and Lglutamate. Growth is absent with the following: D-ribose, L-arabinose, D-xylose, D-glucose, D-fructose, trehalose, Dgalactose, D-mannose, L-rhamnose, maltose, cellobiose, sucrose, lactose, melibiose, salicin, amygdalin, $N$-acetyl-Dglucosamine, glycerol, D-mannitol, myo-inositol, D-sorbitol, D-gluconate, propionate, pyruvate, D-glucuronate, D-galacturonate, D-saccharate, citrate, 2-ketoglutarate, Dglycerate, lactate, trans-aconitate, DL- $\beta$-hydroxybutyrate, L-leucine, L-tyrosine, L-arginine, glycine, L-serine, Lornithine, L-threonine, L-alanine, $\gamma$-aminobutyric acid, Lcitrulline, L-histidine, L-aspartate, L-lysine, L-sarcosine, betaine and putrescine. Intensities (0, negative; 1-5, increasing activity) recorded with the API ZYM gallery are as follows: alkaline phosphatase, 5; esterase (C4), 2; esterase lipase (C8), 3; lipase (C14), 3; leucine arylamidase, 5; valine arylamidase, 2; cystine arylamidase, 1; trypsin, 1; $\alpha$-chymotrypsin, 1 ; acid phosphatase, 3 ; naphthol-AS-BIphosphohydrolase, $1 ; \alpha$ - and $\beta$-galactosidase, $0 ; \beta$-glucuronidase, $0 ; \alpha$ - and $\beta$-glucosidase, $0 ; N$-acetyl- $\beta$-glucosaminidase, $0 ; \alpha$-mannosidase, $0 ; \alpha$-fucosidase, 0 . The only substrates in Biolog GN2 MicroPlates giving clear positives are Tweens 40 and 80 . Weak positive responses are obtained for pyruvic acid methyl ester and succinic acid. The cellular fatty acids, in decreasing order of abundance, are $16: 1 \omega 7 c / 15: 0$ iso $2-\mathrm{OH}, 16: 0,18: 1 \omega 9 c, 10: 03-\mathrm{OH}$, $14: 0,18: 1 \omega 7 c, 10: 0$, unknown fatty acid with an equivalent chain-length of $11.799,18: 0,12: 0,16: 12$ $\mathrm{OH}$ and 16:0 iso. The polar lipid profile consists of phosphatidylglycerol, phosphatidylethanolamine, diphosphatidylglycerol, a phosphoaminolipid (that divides into two spots) and a glycolipid. The DNA G + C content of the type strain is $44.0 \mathrm{~mol} \%$. 
The type strain, $\operatorname{RED65}^{\mathrm{T}}\left(=\mathrm{CECT} 7074^{\mathrm{T}}=\right.$ CCUG $\left.52064^{\mathrm{T}}\right)$, was isolated from surface water collected from the Red Sea.

\section{Acknowledgements}

We are grateful to Dr Jean P. Euzéby for his assistance with the Latin etymology of the new bacterial name. This work was supported by the Swedish Science Council (project 621-2003-2692, to J.P.) and the Spanish Ministerio de Educación y Ciencia (project CGL-2005-02292, to M. J.P.). D. R. A. has a contract with the Universitat de València under the 'Ramón y Cajal' program (Ministerio de Educación y Ciencia, Spain). J. P. acknowledges a postgraduate fellowship from the Ministerio de Educación y Ciencia, Spain.

\section{References}

Arahal, D. R., Lekunberri, I., González, J. M., Pascual, J., Pujalte, M. J., Pedrós-Alió, C. \& Pinhassi, J. (2007). Neptuniibacter caesariensis gen. nov., sp. nov., a novel marine genome-sequenced gammaproteobacterium. Int J Syst Evol Microbiol 57, 1000-1006.

Baumann, P. \& Baumann, L. (1981). The marine gram-negative eubacteria: genera Photobacterium, Beneckea, Alteromonas, Pseudomonas and Alcaligenes. In The Prokaryotes, vol. 2, pp. 13021331. Edited by M. P. Starr, H. Stolp, H. G. Trüper, A. Balows, H. Schleger. Berlin: Springer.

Baumann, L., Baumann, P., Mandel, M. \& Allen, R. D. (1972). Taxonomy of aerobic marine eubacteria. J Bacteriol 110, 402-429.

Bowditch, R. D., Baumann, L. \& Baumann, P. (1984). Description of Oceanospirillum kriegii sp. nov. and O. jannaschii sp. nov. and assignment of two species of Alteromonas to this genus as O. commune comb. nov. and O. vagum comb. nov. Curr Microbiol 10, 221-230.

Giovannoni, S. J. \& Rappé, M. (2000). Evolution, diversity, and molecular ecology of marine prokaryotes. In Microbial Ecology of the Oceans, pp. 47-84. Edited by D. Kirchman. New York: Wiley.

Hagström, Å., Pommier, T., Rohwer, F., Simum, K., Stolte, W., Svensson, D. \& Zweifel, U. L. (2002). Use of 16 S ribosomal DNA for delineation of marine bacterioplankton species. Appl Environ Microbiol 68, 3628-3633.

Kämpfer, P. \& Kroppenstedt, R. M. (1996). Numerical analysis of fatty acid patterns of coryneform bacteria and related taxa. Can J Microbiol 42, 989-1005.

Ludwig, W., Strunk, O., Klugbauer, S., Klugbauer, N., Weizenegger, M., Neumaier, J., Bachleitner, M. \& Schleifer, K.-H. (1998). Bacterial phylogeny based on comparative sequence analysis. Electrophoresis 19, $554-568$.
Ludwig, W., Strunk, O., Westram, R., Richter, L., Meier, H., Yadhukumar, Buchner, A., Lai, T., Steppi, S. \& other authors (2004). ARB: a software environment for sequence data. Nucleic Acids Res 32, 1363-1371.

Macián, M. C., Ludwig, W., Schleifer, K.-H., Garay, E. \& Pujalte, M. J. (2001). Thalassomonas viridans gen. nov., sp. nov., a novel marine $\gamma$ proteobacterium. Int J Syst Evol Microbiol 51, 1283-1289.

Macián, M. C., Arahal, D. R., Garay, E., Ludwig, W., Schleifer, K.-H. \& Pujalte, M. J. (2005). Thalassobacter stenotrophicus gen. nov., sp. nov., a novel marine $\alpha$-proteobacterium isolated from Mediterranean sea water. Int J Syst Evol Microbiol 55, 105-110.

Pinhassi, J. \& Berman, T. (2003). Differential growth response of colony-forming $\alpha$ - and $\gamma$-proteobacteria in dilution culture and nutrient addition experiments from Lake Kinneret (Israel), the eastern Mediterranean Sea, and the Gulf of Eilat. Appl Environ Microbiol 69, 199-211.

Pinhassi, J., Bowman, J. P., Nedashkovskaya, O. I., Lekunberri, I., Gómez-Consarnau, L. \& Pedrós-Alió, C. (2006). Leeuwenhoekiella blandensis sp. nov., a genome-sequenced marine member of the family Flavobacteriaceae. Int J Syst Evol Microbiol 56, 1489-1493.

Pinhassi, J., Pujalte, M. J., Macián, M. C., Lekunberri, I., González, J. M., Pedrós-Alió, C. \& Arahal, D. R. (2007). Reinekea blandensis sp. nov., a marine, genome-sequenced gammaproteobacterium. Int J Syst Evol Microbiol 57, 2370-2375.

Sakane, T. \& Yokota, A. (1994). Chemotaxonomic investigation of heterotrophic, aerobic and microaerophilic spirilla, the genera Aquaspirillum, Magnetospirillum and Oceanospirillum. Syst Appl Microbiol 17, 128-134.

Trüper, H. G. \& Schleifer, K. H. (2006). Prokaryote characterization and identification. In The Prokaryotes: a Handbook on the Biology of Bacteria, 3rd edn, vol. 1, pp. 58-79. Edited by M. Dworkin, S. Falkow, E. Rosenberg, K. H. Schleifer \& E. Stackebrandt. New York: Springer.

Yakimov, M. M., Giuliano, L., Gentile, G., Crisafi, E., Chernikova, T. N., Abraham, W.-R., Lünsdorf, H., Timmis, K. N. \& Golyshin, P. N. (2003). Oleispira antarctica gen. nov., sp. nov., a novel hydrocarbonoclastic marine bacterium isolated from Antarctic coastal sea water. Int J Syst Evol Microbiol 53, 779-785.

Yakimov, M. M., Giuliano, L., Denaro, R., Crisafi, E., Chernikova, T. N., Abraham, W.-R., Luensdorf, H., Timmis, K. N. \& Golyshin, P. N. (2004). Thalassolituus oleivorans gen. nov., sp. nov., a novel marine bacterium that obligately utilizes hydrocarbons. Int J Syst Evol Microbiol 54, 141-148.

ZoBell, C. E. (1946). In Marine Microbiology, vol. XVII, p. 240. Edited by F. Verdoorn. Waltham, MA: Chronica Botanica. 